NOTE

\title{
SOCIAL SCIENCE FINDINGS AND THE JURY'S ABILITY TO DISREGARD EVIDENCE UNDER THE FEDERAL RULES OF EVIDENCE
}

\section{INTRODUCTION}

The Federal Rules of Evidence provide for the exclusion of certain types of evidence from presentation at trial in a variety of situations. Evidence may be held inadmissible because of irrelevance, ${ }^{1}$ prejudicial, misleading, or dilatory effect that substantially outweighs probative value, ${ }^{2}$ or classification in one of several explicit categories of inadmissibility. ${ }^{3}$ Evidence held to be hearsay is generally inadmissible ${ }^{4}$ as is evidence held to be privileged. ${ }^{5}$

When a question of admissibility arises before evidence has been presented, a judge is free to rule on the issue before or during the trial $^{6}$ and may declare a hearing on the issue to be open or closed to the jury, at his discretion. ${ }^{7}$ A motion for such a ruling in advance of the presentation of evidence is a motion in limine, and its use has been encouraged by courts and scholars for its potential to limit the jury's exposure to inadmissible evidence. ${ }^{8}$

There are, however, occasions when inadmissible evidence will find its way before a jury: A permitted question may elicit an answer based on hearsay; a witness may blurt out evidence before a party can object; a count of the complaint may be dropped at trial, rendering previously presented evidence irrelevant. When such situations arise, the party damaged by the presented

Copyright $\odot 1989$ by Law and Contemporary Problems

1. FED. R. Evid. 402.

2. FED. R. EVID. 403.

3. FED. R. Evid. 404 (character evidence is generally inadmissible to prove conformity therewith); Rule 407 (evidence of subsequent remedial measures is generally inadmissible); Rule 408 (evidence of an offer to compromise a claim is generally inadmissible); Rule 409 (evidence of an offer to pay medical expenses is generally inadmissible); Rule 410 (evidence of certain pleadings are per se inadmissible); Rule 411 (evidence of a party's insurance coverage is generally inadmissible); Rule 412 (evidence of a victim's past sexual history is generally inadmissible in a rape case).

4. FED. R. Evid. 802.

5. FED. R. Evid. 501 .

6. FED. R. Evid. 104(a).

7. FED. R. EvID. 104(c); see also FED. R. EvID. 103(c) (advising a closed hearing when potentially prejudicial evidence is involved); FED. R. CIV. P. 43(c) (stating that a court may require a preliminary offer of evidence to be made out of the hearing of a jury).

8. See McCormick on Evinence \& 52, at 128 (3d ed. 1984). See also United States v. Oakes, 565 F.2d 170, 173 (1st Cir. 1977); Gamble, The Motion In Limine: A Pretral Procedure That Has Come of Age. 33 Ala. L. Rev. 1 (1981). 
evidence should make a prompt objection ${ }^{9}$ and move to strike the evidence. If the judge grants this motion, he will instruct the jury to disregard the evidence in question. ${ }^{10}$ When the prejudicial effect of the presented evidence is so grave that no instruction could reverse its impression upon the jury, the court may declare a mistrial.

A related problem occurs when evidence is admissible for some purposes but not others, or as against some defendants but not others." When this type of evidence is admitted, the court should give the jury a limiting instruction, describing the scope of the evidence's purpose in the jury's determinations. ${ }^{12}$

The situations described above give rise to important questions concerning the jury's ability to follow instructions, both to strike and to limit the use of certain evidence. Policies underlying exclusionary rules may be masterfully devised and socially valuable, but they become worthless if juries are unable to follow the instructions that the policies generate. This note will first describe the views of the courts and of the Advisory Committee on the Federal Rules of Evidence on this aspect of jury competence. It will then examine specific theories and experiments drawn from research in the social sciences bearing on the cognitive ability of a jury to disregard evidence, or use it only for limited purposes. After surveying such theories and experiments, this note will attempt to demonstrate their practical implications by analyzing their applicability with respect to a concrete evidentiary issue: the exclusion of a victim's prior sexual history in rape cases under the "rape shield statute" (Federal Rule of Evidence 412). This note will conclude by assimilating these analyses into a discussion of the role of the jury generally.

\section{II}

\section{Views from the Courts and the Advisory Committee on the Jury's Ability to DisRegard}

The effectiveness of instructions to disregard evidence has historically been met with skepticism. Even those institutions that would propose and promote the use of such instructions have expressed some. doubts as to the jury's ability to follow them. Judge Learned Hand called such instructions "recommendation[s] to the jury of a mental gymnastic which is beyond, not only their powers, but anybody's else,"13 and labelled the instructional procedure a legal "placebo." 14 These criticisms have endured to the present. ${ }^{15}$

\footnotetext{
9. See FED. R. Evid. 103(a)(1).

10. See McCormick, supra note $8, \S 52$, at 127.

11. See, e.g., FED. R. Evid. 404(b) (specific acts admissible to show motive or plan, but not to prove character).

12. FED. R. Evid. 105.

13. Nash v. United States, 54 F.2d 1006, 1007 (2d Cir. 1932).

14. United States v. Delli Paoli, 229 F.2d 319, 321 (2d Cir. 1956).

15. See MCCormick, supra note $8, \S 58$, at 150 n. 12.
} 
The Advisory Committee's view of the jury's competence to disregard inadmissible evidence is somewhat ambiguous. In promulgating Rule 105, the Committee manifested a faith that a jury can disregard evidence for certain purposes. However, the Committee adds in a note that the rule repels "any implication that limiting or curative instructions are sufficient in all situations." 16 Further doubt about the jury's ability to follow instructions is apparent in the Committee's requirement that the "effectiveness" of a Rule 105 instruction be a factor in the court's balancing test for admissibility under Federal Rule of Evidence 403.17

The Supreme Court's faith in the jury's ability to disregard improper evidence is similarly tempered. While the Court holds to a "general rule that jury instructions suffice to exclude improper testimony," 18 it has also held, in United States $v$. Bruton, that "there are some contexts in which the risk that the jury will not, or cannot, follow instructions is so great, and the consequences of failure so vital to the defendant, that the practical and human limitations of the jury system cannot be ignored." 19 The Bruton exception to the Court's general trust in the jury has thus far been held narrowly to the Bruton fact situation. ${ }^{20}$ The majority in United States $v$. Richardson stated the strong but less-than-idealistic rationale behind the Court's policy concerning juries and instructions (at least in criminal trials):

The rule that juries are presumed to follow their instructions is a pragmatic one, rooted less in the absolute certitude that the presumption is true than in the belief that it represents a reasonable practical accommodation of the interests of the state and the defendant in the criminal justice process. ${ }^{21}$

The Court's policy stems more from a balancing of interests than from a belief in the jury's ability to understand and follow instructions. Thus, while the Court is more than willing to act upon the presumption that jury members can disregard certain evidence, it is unwilling to profess an outright faith in their competence to do so. The next section will examine the validity of these reservations by analyzing social science findings concerning the jury's cognitive ability to disregard evidence.

16. FED. R. EVID. 105 advisory committee's note.

17. Id.

18. Cruz v. New York, 481 U.S. 186, 191 (1987).

19. United States v. Bruton, 391 U.S. 123, 135 (1968) (limiting instruction held insufficient where non-testifying codefendant's confession names defendant, against whom confession is inadmissible, in joined trial).

20. See Richardson v. Marsh, 481 U.S.200 (1987) (limiting instruction held sufficient where nontestifying codefendant's confession does not expressly implicate defendant). But cf. Cruz, 481 U.S. at 192 (instruction per se ineffective if codefendant's confession "interlocks" with defendant's own confession).

21. Richardson, 481 U.S. at 211. 


\section{III}

\section{Social Science Findings and the Jury's Cognitive Ability to DISREGARD}

The various positions in the social science community with respect to the jury's ability to disregard evidence, like the views of the Advisory Committee and the Supreme Court, are characterized neither by blind faith nor by absolute pessimism. Rather than baldly asserting that the jury can or cannot follow instructions, several social scientists have attempted to look behind jury decisions to learn the cognitive factors that affect the jury's ability in this area. Numerous experiments have been conducted to study this aspect of jury performance. While each one suggests interesting cognitive theories that may underlie jury behavior, it is important to evaluate the validity of this research. In the end, no one theory can adequately explain the jury's behavior in following such instructions. While theories from cognitive psychology no doubt play a role, they are probably supplemented by other, more practical, considerations as factors determining the jury's ability or willingness to disregard or limit the use of evidence.

\section{A. The Effects of Repetition and Memory}

The Chicago Jury Project conducted the first major research concerning the jury's ability to follow instructions to disregard. ${ }^{22}$ Dale Broeder, who participated in the development of the study, reported that when mock jurors were not informed about a defendant's insurance in a tort case (where the defendant's liability was clear), they awarded an average of $\$ 33,000$. In another condition, where the jurors learned that the defendant was insured, the average award was $\$ 37,000$. In the final condition, where jurors were instructed to disregard the fact of coverage, they actually awarded an even greater amount- $\$ 46,000 .^{23}$ Broeder suggested that once the jury learned of the defendant's insurance coverage, the instruction to disregard only reminded them of the fact. Moreover, the "fuss" that was made in objecting to the evidence and in ruling on its admissibility seemed to indicate to jurors that the insurance had a particular importance, and their attention was further drawn to it. ${ }^{24}$

Research in the area of memory and information processing has tended to support this explanation. Repetition and perceived salience are certainly factors that impress data into memory. ${ }^{25}$ In addition, some researchers, most notably Jonathan Casper, have suggested that once a juror hears a fact, it is almost impossible for him to ignore its effects because that fact colors the

22. See Broeder, The University of Chicago Jury Project, 38 NEB. L. REv. 744 (1959).

23. Id. at 754 .

24. Id. Interestingly, the taped deliberations in this study revealed that the admonition to disregard insurance kept jurors from discussing the issue. Nevertheless, the amount of the damage awards indicated that insurance played a role in juror decisionmaking despite silence on the topic during deliberation.

25. See, e.g., G. Loftus \& E. Loftus, Human Memory 7-10, 107-18 (1976). 
juror's thinking of the case as a whole. ${ }^{26}$ This so-called "hindsight bias" "appears to involve an integration of outcome information [or, presumably, inadmissible evidence] into one's understanding of the story, which influences one's judgments about the inevitability of the outcome one has been told, perhaps by affecting recall of material or its weighting." 27 Thus, the more inferences that spring from a given piece of evidence, the more difficult it will be to negate the effect of that evidence by means of a simple instruction to disregard. Indeed, it is often the very impressive, salient, inferencegenerating potential of a particular type of evidence that moves the Advisory Committee to label it as inadmissible per se. ${ }^{28}$ Loftus, Broeder, and, to some degree, Casper theorize that when this information is repeated at trial, its potential relevance only impresses itself further upon the jurors' minds.

This line of thought is consistent with a number of American, British, and Canadian studies finding jurors unable to use evidence for limited purposes. In both the United States and Canada, evidence of a defendant's prior criminal record may be admissible to impeach the defendant but not to prove that the defendant has a criminal propensity. ${ }^{29}$ Studies in both countries have revealed that jurors do not limit their consideration of prior records to the issue of credibility, however. ${ }^{30}$ These studies suggest that once a jury hears of a defendant's past criminal record, it forms conceptions of the evidence and/or the defendant that influence the verdict, and mere instuctions to limit the use of the prior record will not erase those conceptions from the jurors' memories. ${ }^{31}$ Thus, according to these studies, limiting instructions probably have little effect on trial outcomes because it is all but impossible for jurors to forget evidence for one purpose while remembering it for another.

Any theory of jury competence based primarily on memory suffers from certain limitations, however. It is somewhat simplistic to assume that a jury

26. J. Casper, Juror Decision-Making, Attitudes, and the Hindsight Bias (paper presented at Law \& Society Annual Meeting 1987); Saunders, Vidmar, and Hewitt noticed a similar effect operating among mock jurors presented with eyewitness testimony. The researchers found that such testimony may have a continuing effect upon juror evaluations of other evidence and testimony in the trial, even after the eyewitness has been discredited. Saunders, Vidmar \& Hewitt, Eyewitness Testimony and the Discrediting Effect, in Evaluating Witness Evidence 57, 70 (S. Lloyd-Bostock \& B. Clifford eds. 1983).

27. J. Casper, supra note 26, at 4. For a more detailed discussion of the "story" model of evidence evaluation, see generally Pennington \& Hastie, Evidence Evaluation in Complex Decision Making, 51 J. Personality \& Soc. Psychology 242 (1986).

28. See, e.g., FED. R. Evid. 409 advisory committee's note (offers to pay medical expenses inadmissible because this evidence could easily be interpreted as an admission of liability by a party who may only intend the offer as a humanitarian gesture).

29. See Fed. R. Evid. 404(b); Fed. R. Evid. 609; Canada Evidence Act, R.S.C. ch. E-10, § 12 (1970)

30. See generally Doob \& Kirshenbaum, Some Empirical Evidence on the Effect of s. 12 of the Canada Evidence Act upon an Accused, 15 CRIM. L. Q. 88 (1972); Hans \& Doob, Section 12 of the Canada Evidence Act and the Deliberations of Simulated Juries, 18 CRIM. L. Q. 235 (1975); Tanford \& Cox, The Effects of Impeachment Evidence and Limiting Instructions on Individual and Group Decision Making, 12 LAw \& HuM. BeHav. 477 (1988); Wissler \& Saks, On the Inefficacy of Limiting Instructions: When Jurors Use Prior Conviction Evidence to Decide on Guilt, 9 LAw \& HuM. BeHav. 37 (1986). But see Cornish \& Sealy, Juries and the Rules of Evidence, 16 CRIM. L. Q. 208, 217 (1973) (mock jurors able to take account of an instruction to disregard similar convictions as evidence of criminal propensity).

31. See Doob \& Kirshenbaum, supra note 30, at 95; Hans \& Doob, supra note 30, at 251-52; Tanford \& Cox, supra note 30, at 488; Wissler \& Saks, supra note 30, at 44. 
will apply all of the evidence it can recall, regardless of any instruction or circumstance. Research somewhat contradictory to a strict memory theory comes from Cox and Tanford, who note that instructions to disregard were more readily followed than instructions to use evidence for limited purposes. ${ }^{32}$ Similarly, Saunders, Vidmar, and Hewitt found that mock jurors were able in some instances to minimize the impact of testimonial evidence from witnesses who had been discredited. ${ }^{33}$ These results indicate that the process of juror decisionmaking is somewhat more complex than originally contemplated by Broeder. Jurors may not necessarily act on any piece of evidence they remember; while memory of evidence is important, it is not the only factor. Other factors may include the clarity and tone of the instruction, the juror's understanding of the permitted scope of the evidence, and the juror's agreement with the policy behind the instruction. Since Broeder's study did not examine these other factors, it would be unwise to leap to conclusions of total jury incompetence for this task based on the results of the Chicago Jury Project and of similar studies.

\section{B. Reactance Theory}

Wolf and Montgomery ${ }^{34}$ found that the degree of insistence in the judge's instruction to the jury had an effect on the jury's compliance with the instruction: The more insistent the tone, the less likely the jury would be to follow the instruction to disregard. ${ }^{35}$ The two researchers attributed this result to reactance theory. ${ }^{36}$

Reactance theory proposes that when an individual is deprived of the freedom to choose an option, that forbidden option becomes more attractive than it had originally appeared. ${ }^{37}$ Where the threatened option is seen as an important one, the result can be noncompliance with the threatening instruction, or a "boomerang effect," as was apparent in the Broeder study, where an admonition to disregard a defendant's insurance coverage actually resulted in increased awards. ${ }^{38}$

Like theories based in memory, theories based upon the reactance effect do not adequately explain jury performance. The applicability of a reactance theory to jury behavior in disregarding evidence depends upon the ways in which the jury views its role in the trial and whether jurors believe that the

32. M. Cox \& S. Tanford, Evidence and Instructions in Civil Trials 34 (unpublished manuscript).

33. Saunders, Vidmar \& Hewitt, supra note 26 , at 68 . The researchers suggested that judicial instructions could further improve jury performance in this area. Id. at 76.

34. Wolf \& Montgomery, Effects of Inadmissible Evidence and Level of Judicial Admonishment to Disregard on the Judgments of Mock Jurors, 7 J. Applied Soc. Psychology 205, 213 (1977). Sue, Smith, and Caldwell noted a similar tension between judge and jury in their study of conflict theory, to be discussed later. See generally Sue, Smith \& Caldwell, Effects of Inadmissible Evidence on the Decisions of Simulated Jurors: A Moral Dilemma, 3 J. Applied Soc. Psychology 345 (1973).

35. Wolf \& Montgomery, supra note 34, at 217-18.

36. J. Brehm, Psychological Reactance: A Theory of Freedom and Control 35 (1981).

37. Id. at 96.

38. See supra notes 22-24 and accompanying text. 
judge is invading their decisionmaking territory. ${ }^{39}$ While the reactance factor may come into play where the inadmissible evidence is particularly attractive to jurors, or where the judge's manner is particularly unattractive, it is doubtful that the average juror thinks in such grandiose terms about his role as to be offended by a judge merely offering instructions. In fact, since jurors find themselves in an unfamiliar setting in the courtroom and may be confused by trial proceedings, it seems more probable that they would welcome a judge's instructions as helpful guidelines. ${ }^{40}$ True, some jurors may be wary of a counterintuitive instruction to disregard apparently relevant evidence and may fear that in following such an instruction they could be "letting someone off on a technicality." However, where the policy underlying the exclusionary rule is explained to the jury, and where jurors are made to understand the legal task before them, such fears can be minimized, and the degree of reactance may drop considerably. Thus, while reactance may enter into jury decisionmaking to some extent in certain trial situations, it is certainly not the only factor that determines the jury's ability to follow instructions to limit or disregard evidence.

\section{Conflict Theory}

Research by Sue, Smith, and Caldwell ${ }^{41}$ supported earlier studies finding mock jurors unable or unwilling to follow instructions to disregard, especially where there was little admissible evidence available upon which to base a judgment. These researchers noted that jurors instructed to ignore apparently convincing evidence were placed in a "moral dilemma," and that they experienced significant conflict when faced with two undesirable options: ignoring the judge's charge, or reaching an apparently unjust verdict. ${ }^{42}$ These findings suggest that this conflict may be responsible at least in part for undesirable results reached by juries charged to disregard evidence.

Conflict has long been studied as a psychological phenomenon inherent in the decisionmaking process. ${ }^{43}$ Reactions to conflict may include frustration, anger, withdrawal, and deterioration of performance. ${ }^{44}$ Confirmation of conflict as a substantial factor behind poor jury performance comes from studies reported by Park and Borgida and Simon in which mock jurors

39. For a discussion of the jury's ability to act outside of the law, see Kadish \& Kadish, The Institutionalization of Conflict: Jury Acquittals, $27 \mathrm{~J}$. Soc. Issues 199 (1971). See also Scott, Jury Nullification: An Historical Perspective on a Modern Debate, 91 W. VA. L. REv. 389 (1988) (arguing against a jury's right to nullification).

40. See Kassim \& Wrightsman, Coerced Confessions, Judicial Instruction, and Mock Jury Verdicts, $11 \mathrm{~J}$. Applied Soc. Psycholocy 489, $497-98$ (1981) (elaborately instructed jurors show no "boomerang effect").

41. Sue, Smith \& Caldwell, supra note 34 .

42. Id. at 345

43. See, e.g., L. Festinger, Conflict, Decision and Dissonance (1964); I. Janis \& L. Mann, Decision Making 45-80 (1977).

44. L. Festinger, supra note 43 , at 3. 
understood why information was supposed to be disregarded, agreed with that policy (and thus experienced less conflict), and performed better. ${ }^{45}$

The conflict theory may also underlie results from the studies of past criminal record evidence discussed earlier. ${ }^{46}$ Jurors in those studies may not have understood the reasoning behind an instruction not to take a defendant's prior record as evidence of his criminal propensity, and may have experienced a general confusion as to the task before them. This confusion may have led to the jurors' inability to follow the limiting instructions given them. ${ }^{47}$

However, the above experiments, like all jury simulations, cannot be trusted absolutely because there are inevitable questions as to their applicability to the real world. Mock jurors in both the Park and Borgida and the Simon studies were college students-people who may possess views and abilities different from those of the general public. In addition, these mock jurors knew that the situations presented to them were hypothetical and they were therefore perhaps less likely to treat their task with the level of gravity that a real juror would maintain in a real case. ${ }^{48}$ Similarly, the mock jurors in the prior criminal record studies, while more representative of the general public than groups of college students, were also aware of the hypothetical nature of the problems presented to them.

Nevertheless, the conflict theory suggested by these experiments is a commonsense explanation of poor jury performance in disregarding evidence and is supported as a general human tendency in other areas. It is only logical that conflicting undesirable options generate confusion in jurors' minds, which in turn may generate inconsistent or flawed jury decisions. This theory leaves little room for improvement of the system, however. If stress, withdrawal, and poor performance are inevitable reactions to conflict, how are we to avoid the conflict that engenders these reactions? Conflict may be reduced only when jurors happen to know, understand, and agree with the policy behind the evidentiary exclusion. Would an explanation of such policy only reinforce the inadmissible facts in jurors' minds, as was suggested by some studies above? More disturbingly, the conflict theory posits cognitive dissonance as an all but inevitable result of limited-option decisions. ${ }^{49}$ If jurors always experience a degree of cognitive dissonance (akin to regret)

45. See Park \& Borgida, The Entrapment Defense: Juror Comprehension and Decision Making, 12 LAw \& Hum. Behav. 19, 32 (1988) (mock jurors whose "intuitive view" was that prior conviction evidence should not be used against defendants were able to disregard such evidence upon instruction); Simon, Murder, Juries, and the Press, 3 TRANSACtion 40 (1966) (mock jurors, apparently viewing news reports as sensational and irrelevant, able to disregard them upon instruction).

46. See Doob \& Kirshenbaum, supra note 30; Hans \& Doob, supra note 30; Tanford \& Cox, supra note 30; Wissler \& Saks, supra note 30.

47. See, e.g., Wissler \& Saks, supra note 30, at 44 (mock jurors, apparently confused as to their task, admitted to using criminal record evidence to assess guilt even after having been instructed not (o do so).

48. For further discussion of these and other limitations of jury simulations, see Vidmar, Effects of Decision Alternatives on the Verdicts and Social Perceptions of Simulated Jurors, 22 J. Personality \& SoC. Psychology 211,216 (1972).

49. L. FESTINGER, supra note 43 , at 5 . 
after making their decisions, there are disturbing implications concerning the public's level of satisfaction with the judicial system to consider.

\section{Other Theories and Suggestions from Social Scientists}

Among the most important factors not contemplated in the above experiments is the jury's ability to comprehend instructions. ${ }^{50}$ Indeed, significant improvements in jury performance could result from more clearly worded instructions. ${ }^{51}$ Poor jury performance in some cases may result. simply from the jurors' inability to understand the judge's description of their task. ${ }^{52}$ Others have recommended instructing the jury of their implicit right to go outside the law in making their decisions. ${ }^{53}$ While this move would certainly minimize juror conflict, it would probably have a profound and negative impact upon the stability and predictability of the law. ${ }^{54}$ Finally, perhaps the most creative response to this issue offered by social science has been the suggestion of videotaping testimony and then showing it (with inadmissible evidence edited out) to the jury. ${ }^{55}$ Whether the courts will ever adopt such an elaborate and untraditional scheme is doubtful.

The research surveyed above has identified the following factors as having at least some impact upon the jury's ability to follow instructions to disregard evidence or to use it for limited purposes:

1. Repetition of the inadmissible evidence at trial.

2. Perceived salience of the evidence.

3. Style and level of insistence of the judge in delivering the instruction to disregard.

4. Jurors' perceptions of an invasion by the judge of their role in the decision process.

5. Jurors' understanding of and agreement with policies underlying exclusionary rules.

6. Jurors' comprehension of language used in instructions.

50. See Charrow \& Charrow, Making Legal Language Understandable: A Psycholinguistic Study of Jury Instructions, 79 Colum. L. Rev. 1306 (1979); Sales, Elwork \& Alfini, Improving Comprehension for Jury Instructions, in Perspectives in Law \& Psychology 23 (B. Sales ed. 1977); Severance \& Loftus, Improving the Ability of Jurors to Comprehend and Apply Criminal Jury Instructions, 17 LAW \& Soc'Y REv. 153 (1982).

51. See Sales, Elwork \& Alfini, supra note 50, at 27. For examples of rewritten instructions, see Charrow \& Charrow, supra note 50, at 1341-58; Severance \& Loftus, supra note 50, at 185-88.

52. See, e.g., Hans \& Brooks, Effect of Corroboration Instructions in a Rape Case on Experimental Juries, 15 OsGoode Hall L.J. 701, 715 (1978) (mock jurors may have been unable to understand corroboration instructions); Wissler \&: Saks, supra note 30 , at 44 (mock jurors, apparently unaware of the meaning of their instructions, admit to using prior conviction evidence to assess guilt even though they had been instructed not to do so).

53. See, e.g., United States v. Dougherty, 473 F.2d 1113, 1130-37 (D.C. Cir. 1972) (Bazelon, J., dissenting).

54. See Scott, supra note 39 , at 422.

55. See Sue, Smith \& Caldwell, supra note 34 , at 353 (discussing experiment of H.E. Mitchell \& D. Byrne). 
The following section will identify how these factors may apply in a concrete setting: the jury's application of Federal Rule of Evidence 412, the rape shield statute.

\section{IV}

Application of Social Science Findings to a Concrete Evidentiary Policy Issue: The Rape Shield Statute

\section{A. The Mechanics of Federal Rule of Evidence 412}

Among the Federal Rules of Evidence that describe situations in which specific types of evidence become per se inadmissible is Federal Rule 412, the so-called rape shield statute. This rule limits the introduction of past sexual history of a rape victim to instances for which admission is constitutionally required (Rule 412(b)(1)), ${ }^{56}$ instances of sexual behavior with third parties used only to identify the source of blood or semen (Rule 412(b)(2)(A)), and instances of sexual behavior with the accused used to provide evidence on the issue of consent (Rule 412(b)(2)(B)).

The rationale behind the rule is both to "protect a woman from the wholesale exposure of her sexual past" 57 and to reflect an enlightened social policy in which evidence of consent to sex in the past will not be taken as probative of consent on a given occasion. ${ }^{58}$ Indeed, before the reform of exclusionary rules in rape cases, rape trials would often turn into full-scale investigations of the victim's character and private life, which by and large ignored the issue of the defendant's guilt or innocence as to the specific crime charged. ${ }^{59}$ Some critics, arguing that exclusion of sexual history in rape cases should be absolute or nearly so, contend that even after the passage of Federal Rule 412 and similar state legislation, ${ }^{60}$ the courts are still trying the victim and not the accused. ${ }^{61}$ Opponents of an absolute exclusionary rule in these cases cite the constitutional right of a defendant to a reasonable opportunity to present evidence in his defense, and the difficulty of proving consent without some reference to the victim's sexual past. ${ }^{62}$ From a policy standpoint, Rule 412 , with its undefined exception for "constitutionally required" evidence and its general ban on the admission of instances of sexual conduct with third parties, represents an acceptable if vaguely

56. See Tanford \& Bocchino, Rape Victim Shield Laws and the Sixth Amendment, 128 U. PA. L. REv. 544 (1980).

57. S. Estrich, Real Rape 57 (1987).

58. See Borgida, Legal Reform of Rape Laws, in 2 Applied Soc. Psycholocy Ann. 211,212 (L. Bickman ed. 1981).

59. See Tanford \& Bocchino, supra note 56, at 546-51.

60. For a state-by-state analysis of evidentiary rape statutes, see H. FEILD \& L. BIENEN, JURORS and Rape: A Study in Psychology and Law 207-458 (1980).

61. See id. at 173-80; S. EsTrich, supra note 57, at 88 (despite reformed evidentiary laws, defense attorneys report that they still investigate the victim's sexual history and "seek ways to use the information to discredit the victim").

62. See, e.g., Berger, Man's Trial, Woman's Tribulation: Rape Cases in the Courtroom, 77 Colum. L. REV. 1, 98-99 (1977). 
articulated compromise between these two camps. However, even if Rule 412 represents a workable policy with respect to rape cases, one must examine the jury's ability to deal with the rule before pronouncing it valid.

\section{B. Cognitive Skills Required of Jurors by Federal Rule of Evidence 412}

For Rule 412 to be applied effectively at trial, the jurors involved must possess certain cognitive abilities. If prior sexual history evidence finds its way before a jury, that jury must be able to use it in a very precise and limited manner, as described above. Some researchers have questioned the jury's ability to follow Rule 412's guidelines. ${ }^{63}$ For example, under the rule, prior sexual history may not be used to make assumptions about the victim's character. This restriction is a difficult one to follow; studies have shown that jurors tend to view the victim's character as an important factor in rape decisions. ${ }^{64}$ The situation becomes even more difficult if sexual history evidence is admitted at trial for a purpose permissible under Rule 412, such as to prove consent, but the jury is instructed not to consider the evidence as it may bear on the victim's character. Now the jury is faced with the cognitively complex task of using evidence for limited purposes-a job which may well be more intellectually challenging than disregarding evidence in its entirety. ${ }^{65}$

Even when jurors are instructed to disregard evidence completely under Rule 412-as when the source of semen is not in issue and evidence of the victim's sexual conduct with third parties mistakenly gets before a jury-the situtation is problematic. One source of difficulty is that this type of evidence tends to linger in the mind-in accordance with some memory theories discussed above-due to its emotional nature and perceived salience. ${ }^{66}$ In

63. See, e.g., H. Feild \& L. Bienen, supra note 60, at 173.

64. Borgida \& White, Social Perception of Rape Victims: The Impact of Legal Reform, 2 LAw \& HuM. BeHAV. 339 (1978); Feild, Rape Trials and Jurors 'Decisions: A Psycholegal Analysis of the Effects of Victim, Defendant, and Case Characteristics, 3 Law \& Hum. BeHav. 261 (1979); Landy \& Aronson, The Influence of the Character of the Criminal and His Victim on the Decisions of Simulated Jurors, 5 J. ExPERIMENTAL Soc. Psychology 141 (1969). But cf. Reskin \& Visher, The Impacts of Evidence and Extralegal Factors in Jurors' Decisions, 20 LAw \& Soc'y REv. 423, 431 (1986); Visher, Juror Decision Making: The Importance of Evidence, 11 LAW \& HuM. BEHAv. 1, 13 (1987) (both studies noting that while the rape victim's character may enter into juror deliberations, its importance in decisionmaking is not absolute because jurors consider many evidentiary factors in addition to such extralegal elements as victim attributes).

A recent Florida case appears to bear out the theory that victim attributes weigh heavilysometimes decisively-in juror decisionmaking. In October 1989, Steven Lord, the defendant in a Broward County trial, was acquitted of rape and kidnapping charges because jurors believed that his victim "asked for it for the way she was dressed." The victim had testified that the defendant had stolen her car, driven her along a highway, and raped her three times along the roadside at knifepoint. See McCarty, Jury Blames Woman in Rape Case; Drifter Acquitted in Violent Assault, Miami Herald, Oct. 5, 1989, at A1, col. 6. (In March 1990, Lord received a fifty-year sentence after a Georgia jury found him guilty of rape in a separate assault. See Florida Rapist Convicted in Separate Altack, Washington Times, Apr. 20, 1990, at A7.)

65. See Cox \& Tanford, supra note 32 (mock jurors better able to follow instructions to disregard evidence completely than instructions to use evidence for limited purposes).

66. Borgida, Evidentiary Reform of Rape Laws: A Psycholegal Approach, in New DiREctions IN Psycholegal Research 171, 178 (P. Lipsitı \& B. Sales eds. 1980). See also G. Loftus \& E. Loftus, supra note 25 , at 107-18. 
addition, a hindsight bias ${ }^{67}$ may be created by such evidence, causing jurors to view the acts of the defendant in light of their impressions of the victim's character. All of these factors combine to make the disregarding of sexual history in accordance with Rule 412 a challenging task for any jury.

Adding to the jury's difficulties with Rule 412 is the fact that individual jury members may not agree with the social policy behind the rule. Some jurors may still believe that a woman who has consented to sex with others in the past probably consented to sex with the defendant on the given occasion. Worse still, some jurors may assume that a woman's perceived promiscuity has a direct bearing on the gravity of the defendant's conduct in a rape case, and may refuse to punish the accused upon hearing of the victim's prior sexual experiences. ${ }^{68}$ Such beliefs may cause jurors to experience a distressing degree of conflict ${ }^{69}$ when they are told to disregard prior sexual history evidence. Such conflict, in turn, may well cause jurors to ignore their instructions and override the strictures of Rule 412. Of course, if jurors comprehend and agree with the policy behind the exclusionary instruction, the problem of conflict can be minimized. ${ }^{70}$

Finally, in reviewing the difficulties that the federal rape shield statute presents to juries, it is worth noting that as one of the longest and most complex of the Federal Rules of Evidence, Rule 412 will no doubt generate some rather linguistically difficult jury instructions. ${ }^{71}$

\section{Policy Recommendations}

Jurors are faced with a complex cognitive task in dealing with Federal Rule of Evidence 412, and it would be naive to assume that juries could ever apply its provisions with consistent and flawless understanding. However, imperfect jury performance in this area does not excuse a failure on the part of reformers to investigate possible improvements to the system. Poor jury performance in this area need not lead to the resigned hopelessness characteristic of so many litigators and jury specialists. Instead, it should be an incentive toward reform.

Some reformers have suggested the implementation of a stricter or even absolute exclusionary rule regarding prior sexual history. ${ }^{72}$ While such a rule would simplify the jury's job considerably, the promulgation of such a measure would collide impermissibly with the constitutional rights of defendants. ${ }^{73}$

67. See generally J. Casper, supra note 26.

68. See S. Estrich, supra note 57 , at 49.

69. See L. Festinger, supra note 43; I. Janis \& L. MANN, supra note 43.

70. See Kassim \& Wrightsman, supra note 40 (elaborate instruction able to convey policy behind evidentiary rule to jurors); Park \& Borgida, supra note 45.

71. For discussions of the effects of linguistic difficulty on comprehension of jury instructions, see generally Charrow \& Charrow, supra note 50; Sales, Elwork \& Alfini, supra note 50.

72. See, e.g., Borgida, supra note 66, at 192; Feild, supra note 64, at 279.

73. See generally Tanford \& Bocchino, supra note 56. 
A better solution may be to give jurors supplementary or additional instructions explaining the policy behind the rule. Of course, these instructions, like the limiting instructions themselves, should be as clearly worded and comprehensible as possible. Such an explanation would eliminate some of the conflict experienced by jurors faced with the job of deciding rape cases while disregarding certain pieces of evidence. Armed with an understanding of why certain evidence should not be considered, jurors will be less likely to experience conflict and less likely to view their options as limited. In addition, an explanation of underlying policy would eliminate most feelings of reactance or resentment toward the judicial system because jurors would view the procedures to be followed as less arbitrary and more reasonable. Of course, there is always the risk that a long explanation will focus too much attention upon the inadmissible evidence itself, but if the explanation results in a heightened awareness of the dangers of using such evidence, this risk may not pose a significant problem. Indeed, as societal views regarding sexual mores develop, coming more into line with the policies behind Rule 412, the option of explanatory instructions will become even less risky and more attractive.

\section{$\mathrm{V}$ \\ Conclusion}

While juries obviously have problems with the difficult task of disregarding evidence, social science findings may be helpful both in discovering the sources of these problems and in developing recommendations for their alleviation. The courts and the Advisory Committee are correct in continuing to promulgate exclusionary rules and to provide limiting instructions on the assumption that juries will follow them. To do otherwise would be to ignore the potential for improving both instructions and jury performance. While individual jurors may sometimes disagree with the rationales underlying exclusionary rules, and this disagreement may lead to a flawed execution of the jury's task-as in the rape shield situation-there is no reason to abandon the use of limiting instructions, provided they reflect a valid policy. Finally, if judges are aware of the findings of social science in this area, and are willing to experiment, they may devise instructions and procedures more attuned to the jury's true cognitive abilities. Such changes could continually narrow the gap between ideal legal policy and actual jury performance.

Lisa Eichhorn 
